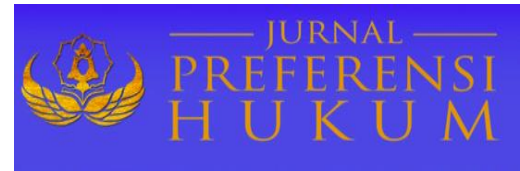

\title{
SANKSI PIDANA BAGI PELAKU PERBUATAN CABUL TERHADAP ANAK DI BAWAH UMUR (STUDI KASUS PUTUSAN NOMOR 29/PID. SUS- ANAK/2018/PN DPS)
}

\author{
I Putu Arta Setiawan, I Wayan Rideng, Ni Made Sukaryati Karma \\ Fakultas Hukum Universitas Warmadewa, Denpasar-Bali, Indonesia
}

\begin{abstract}
Abstrak
Kasus pencabulan terhadap anak marak terjadi sekarang ini. Hal ini merupakan masalah yang menjadi tugas aparat penegak hukum bersama masyarakat untuk memeranginya. Pencabulan terhadap anak dilakukan pelaku untuk memenuhi nafsu birahinya dan juga karena adanya kelainan seksual. Terkait masalah tersebut, pihak penegak hukum khususnya dan masyarakat haruslah berperan aktif untuk melakukan upaya-upaya guna mengatasi permasalahan tersebut. Penjatuhan sanksi merupakan upaya represif yang dapat dilakukan guna memberikan efek jera bagi para pelaku tersebut. Berdasarkan masalah ini, penelitian ini dilakukan untuk menguraikan bagaimana perlindungan hukum terhadap anak korban pencabulan dan bagaimana sanksi bagi pelaku pencabulan terhadap anak. Penelitian ini menggunakan metode normatif, dan data penelitian bersumber dari pendapat para sarjana hukum dan Undang-Undang. Hasil penelitian ini menunjukkan bahwa pemerintah dan masyarakat wajib memberikan perlindungan khusus seperti upaya rehabilitasi dan menjauhkan korban dari labelisasi sekitar atau penderitaan terhadap idetitasnya sebagi korban pencabulan atau kekerasan seksual, sebagaimana Pasal 64 Ayat (1) dan (3) Undang-Undang Nomor 23 Tahun 2002 JO Undang-Undang Nomor 35 Tahun 2014 tentang Perlindungan Anak mengaturnya.Berdasarkan Putusan Nomor 29/Pid. Sus-Anak/2018/PN Dps menetapkan terdakwa BASID memenuhi unsur rumusan dalam Pasal 82 ayat (1) Jo Pasal 76 E undang-Undang perindungan anak Nomor 35 Tahun 2014 tentang perubahan atas Undang-Undang Republik Indonesia Nomor 23 Tahun 2002 tentang perlindungan anak dan dijatuhi pidana 13 (tiga belas) tahun penjara beserta pelatihan kerja di Yayasan Mercy Indonesia Jalan Intan LC II Gang IV No.1 Gatot Subroto Denpasar selama 6 (enam ) bulan lamanya sebagaimana dalam dakwaan tunggal Penuntut umum.
\end{abstract}

Kata Kunci: Pencabulan; Perlindungan Anak; Sanksi Pidana

\begin{abstract}
Cases of molestation against children are rife today. This is a problem that becomes the duty of law enforcement officers and the community to fight. Abuse of children is carried out by offenders to fulfill thier lust and also because of sexual abnormalities. Related to this problem, law enforcement agencies in particular and the community must play an active role in making efforts to overcome these problems. Imposition of sanctions is a repressive effort that can be done to provide a deterrent effect for the perpetrators. Based on this problem, this study was conducted to describe how the legal protection of child victims of sexual abuse and how sanctions for perpetrators of sexual abuse of children. This study used a normative method, and research data are sourced from the opinions of legal scholars and the Law. The results of this study indicate that the government and the community are required to provide special protection such as rehabilitation efforts and keep victims from surrounding labeling or suffering from their identity as victims of sexual abuse or violence, as Article 64 Paragraph (1) and (3) of Law Number 23 Year 2002 JO Law Number 35 of 2014 concerning Child Protection regulates it. Based on Decision Number 29 / Pid. Sus-Anak /2018 / PN Dps determined that the defendant BASID fulfilled the elements of the formulation in Article 82 paragraph (1) Jo Article 76 E of the Child Protection Act No. 35 of 2014 concerning amendments to the Law of the Republic of Indonesia Number 23 of 2002 concerning child protection and was sentenced to 13 (thirteen) years in prison along with job training at Mercy Indonesia Foundation Jalan Intan LC II Gang IV No.1 Gatot Subroto Denpasar for 6 (six) months as in a single indictment of the Public Prosecutor.
\end{abstract}

Keywords: Child Protection; Criminal Sanctions; Sexual abuse 


\section{PENDAHULUAN}

Kejahatan seksual banyak sekali jenisnya, salah satunya adalah tindakan pencabulan yang mana sekarang ini pelakunya tidak lagi mengenal status, ataupun usia korban(Bahri \& Fajriani, 2015). Para pelaku melakukan tindakan keji ini untuk melampiaskan hawa nafsu atau birahinya, yang mana hal ini juga masuk dalam kategori kelainan seksual(Ramdhani, 2017; Setiawan, 2016). Pencabulan terhadap anak di bawah umur khususnya merupakan perbuatan yang tidak dapat dimaafkan, mengingat korbannya adalah anak-anak, sehingga masyarakat tidak dapat menerimanya.

Perbuatan pencabulan ini merupakan perbuatan tercela yang melanggar norma-norma masyarakat terlebih jika korbannya adalah anak-anak di bawah umur yang notabene generasi penerus yang rentan dan rapuh serta dapat mengalami trauma berkepanjangan(Annisa, 2014; Zuleha, 2015).Pencabulan masuk ke dalam jenis tindak pidana kesusilaan yaitu penggolongannya diatur dalam Kitab UndangUndang Hukum Pidana (KUHP) pada BAB XIV Buku ke- II yakni dimulai dari pasal 289 sampai dengan pasal 296 Kitab Undang-Undang Hukum Pidana, dalam pasal 289 Kitab Undang-Undang Hukum Pidana mengatur mengenai kejahatan terhadap kesusilaan biasa, yaitu dengan ancaman hukuman sembilan tahun penjara. Upaya preventif dan represif juga dapat dilakukan (Hadjon, 2008:2).

Kasus pencabulan terhadap anak masih banyak terjadi di sekitar kita, sehingga perlu adanya perlindungan terhadap korban dan penjatuhan sanksi pidana yang sesuai terhadap para pelaku. Salah satu contoh kasus pencabulan yang cukup menghebohkan yang terjadi terhadap anak perempuan berusia 5 tahun dengan inisial NF di Jalan Taman Griya, Tuban, Kuta, Bali, dimana pelakunya berusia 17 tahun berinisial BS. Kejahatan telah terjadi sebanyak dua kali di daerah sekitar tempat tinggal korban (Bali Express Jawa Pos, 2019, pukul 23.49 Wita.).

Ini membuktikan bahwa aparat penegak hukum harus tegas menegakkan hukum terkait kasus kekerasan seksual yang menimpa anak di bawah umur, sehingga dapat menimbulkan efek jera bagi para pelaku(Khairida, Syahrizal, \& Din, 2017; Sitompul, 2015). Untuk itu penerapan sanksi pidana yang sesuai menjadi salah satu upaya untuk memberikan perlindungan bagi korban karena perlindungan hukum terhadap korban haruslah datang dari berbagai pihak, sehingga menjamin kesehatan mental terutama dan juga fisik korban ke depannya.

Berdasarkan latar belakang di atas, penelitian ini dilakukan dengan tujuan mendeskripsikan bagaimana perlindungan hukum terhadap anak korban pencabulan dan bagaimana sanksi bagi pelaku pencabulan terhadap anak.

\section{METODE}

Penelitian ini didesain dengan menggunakan pendekatan penelitian hukum normatif, artinya penelitian ini dilakukan berdasarkan perundang-undangan. Sumber data penelitian ini berbentuk data sekunder yang diperoleh dari Undang-Undang, hasil penelitian, dan koran. Data dikumpulkan dengan cara studi kepustakaan. Analisis data dilakukan dengan menggunakan metode kualitatif, dan hasil analisis data disajikan secara deskriptif.

\section{HASIL DAN PEMBAHASAN}

\section{Perlindungan Hukum terhadap Anak Korban Pencabulan}

Setiap perbuatan pidana haruslah memenuhi unsur-unsur dari tindak pidana tersebut, termasuk pula dalam tidak pidana kekerasan seksual atau pencabulan. Bentuk perlidungan hukum terhadap anak selaku korban ada berupa upaya preventif atau pencegahan, adapula represif yaitu penindakan atau penyelesaian kasus (Hadjon, 1987).

Doek dan Drewes dalam Wadong (2000) mengelompokkan perlindungan anak ke dalam dua bagian yaitu:

a. Dalam pengertian luas, hukum perlindungan anak merupakan setiap aturan yang mana memberikan perlindungan terhadap anak agar dapat berkembang.

b. Dalam arti sempit, hukum perlindungan anak dibedakan menjadi tiga yaitu dalam ketentuan hukum pidana, perdata, dan hukum acara.

Adapun perlindungan hukum yang diberikan kepada anak oleh Kitab Undang-Undang Hukum Pidana sebagai berikut (Prints, 1997).

a. Menjaga agar anak berperilaku sopan;

b. Pemberian Larangan untuk melakukan hal-hal yang dibawah umur seperti hubungan intim dengan oranglain atau orang dewasa; 
c. Larangan untuk melakukan perbuatan cabul terhadap anak lain.

Setiap anak memiliki hak-haknya, dimana dalam Bab III Undang-Undang Nomor 23 Tahun 2002 tentang Hak dan Kewajiban Anak telah menjelaskan beberapa hak serta kewajiban yang dimiliki setiap anak. Adapun hak-hak yang dimiliki seorang anak antara lain:

a. Hak hidup, tumbuh, berkembang, sebagaimana hak asasi manusia mengaturnya. Selain itu, anak-anak juga memiliki hak atas perlindungan dari adanya tindakan kekerasan maupun diskriminasi.

b. Hak untuk memiliki identitas dirinya seperti anak dan status kewarganegaraan.

c. Hak untuk beribadah sesuai kepercayaan dan agamanya. Selain itu, ia memiliki hak untuk berfikir serta berekspresi sesuai dengan usia dan kemampuannya, dengan pengawasan dan bimbingan orang tua.

d. Hak untuk mendapatkan pendidikan yang layak atau patut untuk mengembangkan dirinya serta kemampuannya.

e. Hak untuk mendapatkan perlindungan hukum dari kejahatan-kejahatan yang dapat menimpa mereka, dan berhak atas diskresi sesuai hukum yang berlaku.

f. Setiap anak berhak atas bantuan hukum dan pembelaan diri jika ia merupakan korban perambpasan kebebasan yang mana setiap orang diperlakukan sama dihadapan hukum. Dan salaam proses peradilan harus dirahasiakan dan dilakukan tertutup bagi umum.

Menurut Undang-Undang Nomor 35 Tahun 2014 tentang Perubahan atas Undang-Undang Nomor 23 Tahun 2002 tentang Perlindungan Anak, Orang Tua, Keluarga, bahkan pemerintah dan negara wajib bertanggung jawab memberikan perlindungan bagi setiap anak, termasuk pula masyarakat di sekitarnya. Tidak ada pembedaan suku, ras, agama ataupun golongan dalam hal ini karena setiap anak memilki jati diri sendiri dan special sehingga diskriminasi tidak dapat dilakukan.

Pembentukan Komisi perlindungan Anak Indonesia (KPAI) merupakan salah satu upaya yang dilakukan pemerintah untuk kepentingan perlindungan terhadap anak. Komisi ini merupakan Lembaga Independen yang dibentuk sebagai pelaksanaan atas Undang-Undang Nomor 23 Tahun 2003. Adapun tujuan utama dari pembentukan lembaga ini adalah untuk meningkatkan efektifitas penyelanggaraan perlindungan terhadap anak-anak.

Perlindungan Hukum terhadap anak merupakan upaya penjaminan serta melindungi anak serta hak-haknya dari perilaku-perilaku yang tidak bermoral, sehingga menjamin perlindungan terhadap mental dan kondisi fisik anak sebagaimana diatur dalam Pasal 1 Ayat (2) Undang-Undang Nomor 23 Tahun 2002 Jo Undang-Undang Nomor 35 Tahun 2014 Jo. Peraturan Pemerintah Pengganti UndangUndang (Perppu) Nomor 1 Tahun 2016 tentang Perlindungan Anak. Negara memberikan perlindungan hukum bagi anak sebagaimana diatur dalam undang-undang. Permasalahan terkait anak yang menjadi korban pencabulan merupakan kasus penting, yang penangannya harus dilakukan dengan baik, sehingga anak tidak mengalami trauma berkepanjangan dan mempengaruhi mental mereka. Oleh karena itu, upaya penyelesaian kasusnya haruslah dilakukan dengan didampingi para ahli yang kompeten termasuk orang tua mereka. Upaya pendampingan korban hingga pembinaan mental harus terus dilakukan sedemikian rupa untuk membantu pemulihan mental dan fisik anak. Perlindungan hukum yang didasarkan pada Undang-Undang Nomor 23Tahun 2002 Jo Undang-Undang Nomor 35 Tahun 2014 Tentang Perlindungan Anak serta aturan-aturan lain yang merupakan pentuk proteksi kepada anak yang menjadi korban tindak pidana pencabulan. Pemerintah dan masyarakat wajib memberikan perlindungan khusus seperti upaya rehabilitasi dan menjauhkan dari labelisasi sekitar atau penderitaan terhadap idetitasnya sebagi korban pencabulan atau kekerasan seksual, sebagaimana Pasal 64 Ayat (1) dan (3) Undang-Undang Nomor 23 Tahun 2002 JO Undang-Undang Nomor35 Tahun 2014 tentang Perlindungan Anak mengaturnya.

Ada pula produk hukum yang mengatur terkait kekerasan seksual atau pencabulan terhadap anak dalam Undang-Undang Nomor 35 Tahun 2014 tentang perubahan Undang-Undang Nomor 23 Tahun 2002, dimana dalam Pasal 82 Ayat (1) hukuman yang dapat dikenakan 5 (lima) hingga 15 (lima belas) tahun penjara dengan denda hingga Rp 5.000.000.000,00 (lima miliar), namun apabila pencabulan dilakukan oleh orang terdekat korban seperti orang tua, pendidik, pengasuh, dan sebagainya maka pidananya ditambah $1 / 3$ (sepertiga) dari yang tersebut sebelumnya.

Pengaruh media massa sekarang ini juga cukup pesat, sehingga perlu adanya pembatasan terkait pemberitaan pencabulan anak karena disini korbanlah yang sangat dirugikan(Safaruddin Harahap, 
2016). Perlindungan terhadap identitas korban perlu dijaga untuk menghindari persekusi di masyarakat serta stigma yang menganggap korban merupakan seorang yang harus dijauhi. Inilah yang juga perlu diperangi pemerintah dan orang di sekitar korban, sehingga mental korban yang terbebani akibat kasus ini dapat pulih kembali, dan dapat melupakan kejadian pahit tersebut.

\section{Sanksi Pidana Bagi Pelaku Perbuatan Cabul Terhadap Anak}

Sanksi Pidana merupakan bentuk hukuman yang menerapkan prinsip kausalitas atau sebab akibat. Sanksi pidana diberikan sebagai bentuk perlindungan hukum bagi korban dan upaya memberikan hukuman yang sesuai dengan tindakan pelaku dan diharapkan memberikan efek jera. Sanksi pidana haruslah menjamin pelaku untuk tidak mengulangi perbuatannya di kemudian hari, seperti bentuk rehabilitasi perilaku dari pelaku kejahatan tersebut. Namun tidak jarang bahwa sanksi pidana diciptakan sebagai suatu ancaman dari kebiasaan manusia itu sendiri (Andrisman, 2009).

Jenis-jenis sanksi pidana dapat kita temukan pengaturannya dalam Pasal 10 Kitab UndangUndang Hukum Pidana (KUHP) yaitu ada pidana pokok dan pidana tambahan. Hukuman atau sanksi bagi para pelaku pencabulan terhadap anak dapat kita lihat pengaturannya dalam Pasal 82 Ayat (1) Undang-Undang Nomor 35 Tahun 2014 Tentang Perubahan Atas Undang- Undang Nomor 23 Tahun 2002 Tentang Perlindungan Anak, yaitu berupa ancaman pidana penjara beserta denda pula dengan nilai yang tidak sedikit yakni paling singkat 5 (lima) tahun dan paling lama 15 (lima belas) tahun sedangkan untuk denda dapat mencapai Rp. 5.000.000.000,00 (lima milyar rupiah).

Tujuan pemidanaan pada hakikatnya untuk mencegah kejahatan berulang dilakukan oleh terpidana atau pelaku pada masa yang akan datang. Konteks yang dikatakan Hugo De Groot "malim pasisionis propter malum actionis" yaitu sama dengan prinsip bahwa kita menuai apa yang kita tanam, jika kita melakukan perbuatan jahat, maka kita menanggung penderitaan jahat pula sebagai gantinya. Terdapat perbedaan pendapat terkait pemidanaan, di satu sisi dikatakan bertujuan sebagai pembalasan (teori absolut) di sisi lain bertujuan positif, dan ada pula teori gabungan antara keduanya (Kholiq \& Wibowo, 2016; Muladi, 2008).

\section{a. Kasus dan Analisa Putusan Nomor 29/pid. Sus-anak/2018/pn dps}

1. Posisi Kasus

1.1 Kedudukan Perkara

Bahwa berawal pada hari Jumat tanggal 18 Mei 2018 sekitar Pukul 14.00 WITA, anak atas nama BASID membakar sampah di halaman kos anak nama BASID di Jalan Taman Griya I Nomor 2G, Kecamatan Kuta, Kabupaten Badung melihat saksi NADIFATUL HILMIYAH seorang diri, oleh karena anak atas nama BASID sering menonton film porno di Handphone miliknya, timbul niat anak atas nama BASID untuk mencabuli saksi NADIFATUL HILMIYAH, niat tersebut anak atas nama BASID laksanakan dengan cara anak atas nama BASID mengatakan kepada saksi NADIFATUL HILMIYAH "Dif, Main yuk, main gitu-gituan", sambil anak atas nama BASID dengan tangannya menunjuk alat kemaluan terdakwa, kemudian anak atas nama BASID mengajak saksi NADIFATUL HILMIYAH ke halaman parkir tempat kost di Jalan Taman Griya I Nomor 2G, Kecamatan Kuta, Kabupaten Badung yang jaraknya kurang lebih 10 (sepuluh) meter, kemudian anak atas nama Basid dengan sekuat tenaga dengan menggunakan kedua tangannya menaikkan kemudian menidurkan atau membaringkan saksi NADIFATUL HILMIYAH ke atas kap mobil yang sedang terparkir, setelah itu anak atas nama BASID membuka kedua kaki saksi NADIFATUL HILMIYAH dan membuka celana yang saksi NADIFATUL HILMIYAH kenakan, setelah itu anak atas nama BASID membuka resleting yang anak atas nama BASID kenakan, kemudian anak atas nama BASID memegang kemaluannya atau penisnya yang dalam keadaan tegang, lalu anak atas nama BASID menggosok-gosok kemaluannya atau penisnya di kemaluan atau vagina saksi NADIFATUL HILMIYAH berkali-kali atau setidak-tidaknya lebih dari 1 (satu) kali hingga anak atas nama BASID merasa puas, oleh karena saksi NADIFATUL HILMIYAH tidak memiliki tenaga yang cukup sehingga saksi NADIFATUL HILMIYAH tidak dapat melakukan perlawanan.

Bahwa perbuatan anak atas nama BASID sebagimana tersebut di atas menyebabkan saksi NADIFATUL HILMIYAH mengalami luka memar pada bibir kecil kemaluan dan luka lecet pata lutut akibat kekerasan tumpul, sebagimana diterangkan dalam Visum Et Revertum Nomor YR.02.03/XIV.4.4.7/257/2018 tanggal 21 Mei 2018 yang dibuat dan ditandatangani oleh dr. 
HENKY, Sp.F., M.Biothics dokter pemerintah pada instalasi Kedoteran Forensik Rumah Sakit Umum Pusat Sanglah Denpasar.

1.2 Tuntutan Jaksa

Setelah mendengar pembacaan surat tuntutan pidana Penuntut Umum yang pada pokoknya sebagai berikut.

a. Menyatakan anak BASID secara sah terbukti melakukan perbuatan sesuai rumusan pasal82 ayat (1) Jo pasal76 E Undang-Undang Perlindungan Anak Nomor 35 Tahun 2014 perubahan atas Undang- Undang Nomor 23 Tahun 2002. Unsur-unsur yang terpenuhi sehingga dinyatakan bersalah melakukan kekerasan atau ancaman kekerasan, dengan cara memaksa, ataupun melalui tipu muslihat, berbohong hinga membujuk atau mendorong serta membiarkan anak untuk dilakukannya perbuatan cabul. Untuk itu dimasukkan dalam dakwaan tunggal Penuntut Umum;

b. Menjatuhkan sanksi Pidana terhadap Anak BASID dikurangi selama berada dalam rumah tahanan sementara yaitu dengan pidana penjara selama 2 (dua) tahun. Selanjutnya dijatuhkan pidana pelatihan kerja sepanjang 6 (enam) bulan sehingga diharuskan tetap untuk ditahan di Yayasan Mercy Indonesia tepatnya di jalan Intan LCII Gang IV No. 1 Gatot Subroto Denpasar

c. Menyatakan barang bukti berupa:

- 1 (satu) buah celana dalam warna putih bergambar hewan telah kembali pada yang berhak yaitu saksi SOVIA

- 1 (satu) buah baju dress warna merah

- 1 (satu) buah baju kaos lengan pendek warna biru bertuliskan Billabong

- 1 (satu) buah celana kainpendek warna hitammotif kotak dirampas untuk dimusnahkan

d. Menetapkan agar Anak BASID dibebani membayar biaya perkara sebesar Rp. 1.000,- (seribu rupiah)

2. Analisa Kasus

Kasus tersebut di atas merupakan salah satu kasus pencabulan terhadap anak di bawah umur, yang telah melalui proses peradilan dan telah diputuskan oleh hakim. Kasus berawal dari dilakukan pebuatan pidana oleh terdakwa BASID terhadap korban NADIFATUL HILMIYAH dan terbukti melakukan perbuatan cabul di sekitaran tempat tinggal korban. Ketentuan pidana yang didakwakan oleh jaksa penuntut umum terhadap kasus ini ada beberapa pasal yaitu Pasal 82 ayat (1) Jo Pasal 76 E UndangUndang Perlindungan Anak Nomor 35 Tahun 2014 Tentang Perubahan Atas Undang-Undang Republik Indonesia Nomor 23 Tahun 2002 tentang Perlindungan anak dalam putusan perkara pidana Pengadilan Negeri Denpasar Nomor 29/Pid.Sus-Anak/2018/PN Dps menyatakan bahwa terdakwa secara sah terbukti melakukan perbuatan sesuai rumusan pasal 82 ayat (1) Jo pasal 76 E Undang-Undang Perlindungan Anak Nomor 35 Tahun 2014 perubahan atas Undang-Undang Nomor 23 Tahun 2002. Unsur-unsur yang terpenuhi sehingga dinyatakan bersalah dilakukannya kekerasan atau ancaman kekerasan, dengan cara memaksa, ataupun melalui tipu muslihat, berbohong hingga membujuk atau mendorong serta membiarkan anak untuk dilakukannya perbuatan cabul. Untuk itu dimasukkan dalam dakwaan tunggal Penuntut Umum dan Menjatuhkan sanksi Pidana terhadap Anak BASID dikurangi selama berada dalam rumah tahanan sementara, yaitu dengan pidana penjara selama 2 (dua) tahun yaitu total 13 (tiga belas) tahun penjara. Selanjutnya dijatuhkan pidana pelatihan kerja sepanjang 6 (enam) bulan sehingga diharuskan tetap untuk ditahan di Yayasan Mercy Indonesia tepatnya di jalan Intan LC II Gang IV No.1 Gatot Subroto Denpasar.

Membaca putusan Majelis Hakim Pengadilan Negeri Denpasar, menurut penulis putusan yang diambil tidak memiliki rasa keadilan, karena hakim terlalu ringan dalam memberikan sanksi terhadap terdakwa BASID.Pelecehan terhadap korban menyebabkan derita fisik serta psikologis, yang untuk menyembuhkannya tidak dalam hitungan hari, akan tetapi membutuhkan waktu yang sangat lama.Oleh karena itu, diharapkan agar Majelis Hakim memberikan Putusan sesuai Undang-Undang yang berlaku untuk memberikan efek jera bagi pelaku agar kasus serupa tidak aka ada lagi.

\section{SIMPULAN DAN SARAN}

\section{Simpulan}

Berdasarkan hasil analisis data penelitian ini, ada beberapa simpulan yang perlu dibuat, yaitu: pertama, perlindungan hukum terhadap anak korban pencabulan dilakukan dengan upaya yang bersifat preventif maupun yang bersifat represif, baik yang lisan maupun yang tertulis. Dengan ini perlindungan 
merupakan cerminan dari pelaksanaan dari tujuan dan fungsi hukum itu sendiri yaitu memberikan kepastian, kemanfaatan serta keadilan bagi setiap masyarakat dalam hal ini anak selaku korban pencabulan atau kekerasan seksual. Kedua, Sanksi bagi pelaku pencabulan terhadap anak diatur dalam Pasal 82 Ayat (1) Undang-Undang Nomor 35 Tahun 2014 Tentang Perubahan Atas Undang-Undang Nomor 23 Tahun 2002 Tentang Perlindungan Anak, menetapkan sanksi bagi terpidana atau pelaku pencabulan terhadap anak di bawah umur yakni dengan ancaman pidana setidaknya 5 (lima) tahun bahkan hingga 15 (lima belas) tahun beserta denda hingga dapat mencapai Rp. 5.000.000.000, 00 (lima milyar rupiah).

\section{Saran}

Sesuai dengan hasil penelitian ini, ada beberapa saran yang perlu disampaikan kepada beberpa pihak, yaitu: bagi Pemerintah dalam hal ini sebagai pejabat yang memiliki kewenangan, setidaknya mengkaji ulang Undang-Undang Perlindungan Anak terkait sanksi bagi pelaku pencabulan, agar hal tersebut tidak terulang kembali agar memberikan efek jera bagi pelaku pencabulan, dan bagi para penegak hukum seperti kepolisian, kejaksaan dan kehakiman agar memberikan putusan yang setimpal sesuai dengan ketentuan Undang-Undang bagi pelaku pencabulan terhadap anak agar tidak ada lagi anak yang menjadi korban kejahatan seksual terutama pencabulan anak.

\section{DAFTAR PUSTAKA}

Andrisman, T. (2009). Asas-Asas dan Dasar Aturan Hukum Pidana Indonesia. Bandar Lampung: Unila. Annisa, F. (2014). Penegakkan Hukum terhadap Anak yang Melakukan Tindak Pidana Pencabulan dalam Konsep Restorative Justice. ADIL: Jurnal Hukum, 7(2), 202-211. Retrieved from https://media.neliti.com/media/publications/135021-ID-penegakkan-hukum-terhadap-anak-yangmela.pdf

Bahri, S., \& Fajriani. (2015). Suatu Kajian Awal terhadap Tingkat Pelecehan Seksual di Aceh. 9(1), 50-65. https://doi.org/10.13170/jp.9.1.2491

Hadjon, P. M. (1987). Perlindungan Hukum bagi Rakyat Indonesia. Surabaya: PT. Bina Ilmu.

Khairida, Syahrizal, \& Din, M. (2017). Penegakkan Hukum terhadap Pelaku Tindak Pidana Pelecehan Seksual pada Anak dalam Sistem Peradilan Jinayat. Syiah Kuala Law Jurnal, 1(2), 169-186. Retrieved from http://www.jurnal.unsyiah.ac.id/SKLJ/article/view/8472

Kholiq, M. A., \& Wibowo, A. (2016). Penerapan Teori Tujuan Pemidanaan dalam Perkara Kekerasan terhadap Perempuan: Studi Putusan Hakim. Jurnal Hukum IUS QUIA IUSTUM, 23(2), 186-205. https://doi.org/10.20885/iustum.vol23.iss2.art2

Muladi. (2008). Lembaga Pidana Bersyarat. Bandung: Alumni.

Prints, D. (1997). Hukum Anak Indonesia. Bandung: Citra Aditya Bakti.

Ramdhani, I. (2017). Kasus Pelecehan Seksual dalam Transportasi Umum Menurut Putusan Pengadilan Negeri Jakarta Pusat. SALAM: Jurnal Sosial Dan Budaya Syar-I, 4(1), 95-120. https://doi.org/10.15408/sjsbs.v4i1.7871

Safaruddin Harahap, I. (2016). Perlindungan Hukum terhadap Anak Korban Kejahatan Seksual dalam Perspektif Hukum Progresif. Jurnal Media Hukum, 23(1), 37-47. https://doi.org/10.18196/jmh.2015.0066.37-47

Setiawan, E. (2016). Kejahatan Seksual Pedofilia Dalam Perspektif Hukum Pidana dan Islam. Jurnal Hukum Islam, 14(2), 1-15. https://doi.org/10.1017/CBO9781107415324.004

Sitompul, A. H. (2015). Lex Crimen. IV(1), 46-56. Retrieved from https://media.neliti.com/media/publications/3219-ID-kajian-hukum-tentang-tindak-kekerasanseksual-terhadap-anak-di-indonesia.pdf

Wadong, M. H. (2000). Advokasi dan Hukum Perlindungan Anak. Jakarta: Grasindo.

Zuleha. (2015). Perlindungan Hukum Terhadap Anak Korban Pemerkosaan dalam Perspektif Viktimologi. Jurnal Hukum Samudra Keadilan, 10(1), 125-133. Retrieved from http://journal.uinjkt.ac.id/index.php/salam/article/download/7871/pdf

Kitab Undang-Undang Hukum Pidana Undang-Undang Nomor 35 Tahun 2014 Tentang Perubahan Atas Undang-Undang Nomor 23 Tahun 2002 Tentang Perlindungan Anak 